\title{
Influence of ensiling, exogenous protease addition, and bacterial inoculation on fermentation profile, nitrogen fractions, and ruminal in vitro starch digestibility in rehydrated and high-moisture corn
}

L. F. Ferraretto, S. M. Fredin, and R. D. Shaver ${ }^{1}$

Department of Dairy Science, University of Wisconsin, Madison 53706

\section{ABSTRACT}

Exogenous protease addition may be an option to increase proteolysis of zein proteins and thus starch digestibility in rehydrated and high-moisture corn (HMC) ensiled for short periods. In addition, microbial inoculation may accelerate fermentation and increase acid production and thus increase solubilization of zein proteins. Four experiments were performed to evaluate the effect on fermentation profile, $\mathrm{N}$ fractions, and $\mathrm{ru}-$ minal in vitro starch digestibility (ivSD) of the following: (1) rehydration and ensiling of dry ground corn; (2) exogenous protease addition to rehydrated un-ensiled and ensiled corn; (3) exogenous protease addition or inoculation in rehydrated ensiled corn; and (4) exogenous protease addition or inoculation in HMC. Experiments 1,2 , and 3 were performed with 7 treatments: dry ground corn (DGC); DGC rehydrated to a targeted dry matter content of $70 \%(\mathrm{REH})$; REH treated with exogenous protease $(\mathrm{REH}+)$; REH ensiled for $30 \mathrm{~d}$ (ENS); ENS treated with exogenous protease (ENS+); ENS treated with a microbial inoculant containing Lactobacillus plantarum, Lactobacillus casei, Enterococcus faecium, and Pediococcus sp. (ENSI); and ENS treated with exogenous protease and microbial inoculant (ENSI+). Experiment 1 compared DGC, REH, and ENS with ivSD being greater for ENS $(64.9 \%)$ than DGC and REH ( $51.7 \%$ on average). Experiment 2 compared REH and ENS without or with exogenous protease addition (REH+ and ENS+, respectively). Ensiling and exogenous protease addition increased ivSD, but exogenous protease addition was more effective in ENS than REH (6.4 vs. 2.6 percentage unit increase). Experiment 3 compared the effects of exogenous protease addition and inoculation in ENS corn (ENS, ENS+, ENSI, and ENSI+). The addition of protease, but not inoculant, increased ivSD. Inoculation reduced $\mathrm{pH}$ and acetate,

Received June 1, 2015.

Accepted June 24, 2015.

${ }^{1}$ Corresponding author: rdshaver@wisc.edu propionate, and ethanol concentrations, and increased lactate and total acid concentrations. In experiment 4, 8 treatments were a combination of HMC noninoculated or inoculated with 1 of 3 microbial inoculants and with or without exogenous protease addition. The inoculant treatments contained (1) Lactobacillus buchneri 40788 and Pediococcus pentosaceus, (2) L. buchneri 40788, and (3) a mixture of $P$. pentosaceus and Propionibacterium freudenreichii. Protease, but not inoculation, increased ivSD by 7.5 percentage units ( 44.4 vs. $51.9 \%$ ). Protease addition increased ivSD in rehydrated corn and HMC. Microbial inoculation improved fermentation profiles but did not affect ivSD.

Key words: corn, protease, inoculant, ruminal in vitro starch digestibility

\section{INTRODUCTION}

Corn grain is the predominant feed energy source in the US livestock industry with approximately 122 million tonnes fed during the 2014-2015 season (USDAERS, 2015). Starch composes approximately $70 \%$ (DM basis) of corn grain and accounts for $75 \%$ of its energy value for dairy cattle (calculated from NRC, 2001). Therefore, improvements in starch digestibility may improve lactation performance by dairy cows.

Greater starch digestibility and lactation performance by dairy cows fed high-moisture corn (HMC) compared with dry ground shelled corn (DGC) are consistently reported in the literature as evidenced by reviews of Firkins et al. (2001) and Ferraretto et al. (2013). This is likely related to the reduction in zein protein subunits that cross-link starch granules during the ensiling process (Hoffman et al., 2011). Digestibility of starch is mainly influenced by this hydrophobic starch-protein matrix surrounding starch granules that impedes microbial attachment and fermentation in the rumen or hydrolytic and enzymatic digestion in the abomasum and small intestine (Giuberti et al., 2014). Furthermore, factors such as mean particle size (MPS), harvest maturity and moisture content, and endosperm type may alter the starch-protein matrix, and thus, the 
extent of starch digestibility for HMC (Giuberti et al., 2014).

Recent reports indicate that an extended ensiling period increases ruminal in vitro starch digestibility (ivSD; Ferraretto et al., 2014; Kung et al., 2014), underscoring that maximum starch digestibility occurs only after several months of storage. To help overcome this lag, 2 options may merit consideration. First, addition of exogenous protease at ensiling has enhanced the breakdown of zein proteins and increased ivSD (Kung et al., 2014). Second, $\mathrm{pH}$ has an inverse relationship with ivSD (Ferraretto et al., 2014) and pH decline is associated with greater concentrations of organic acids (Muck, 2010). Perhaps reduced pH and greater concentrations of organic acids associated with the addition of microbial inoculants at ensiling may increase zein protein solubilization and thereby starch digestibility. In addition, a combination of these factors (exogenous protease plus microbial inoculant) may potentiate the increase in starch digestibility of HMC.

Rehydration and ensiling of DGC became a common practice in Brazil in recent years due to limited machinery availability and excessive rainfall during the HMC harvest period, which can delay harvest (Bitencourt, 2012). Delayed harvest, and the corresponding decrease in DM content, for HMC may impair silo fermentation and reduce ivSD (Goodrich et al., 1975; Ferraretto et al., 2014). Benton et al. (2005b) reported similar in situ DM disappearance for HMC and rehydrated and ensiled DGC after 28-d fermentations. In addition, beef steers were more efficient (measured as feed:gain ratio) when rehydrated and ensiled corn or sorghum were used in comparison with their dry-rolled counterparts (Stock et al., 1987; Benton et al., 2005a). Perhaps rehydration and ensiling of DGC may be an alternative in areas where HMC harvest and fermentation may be compromised by weather conditions (e.g., excessive rainfall, freezing temperatures), limited by machinery availability, or both. Literature, however, is scarce in this area. Furthermore, benefits of microbial inoculation or exogenous protease addition in rehydrated and ensiled DGC are unknown.

Although reports evaluating exogenous protease addition to HMC exist in the literature (Kung et al., 2014), research evaluating its use in combination with varied microbial inoculants commonly used in the industry is warranted. Furthermore, although the benefit of increasing DM digestibility of DGC through rehydration and ensiling has already been reported (Benton et al., 2005a,b), research evaluating potential benefits of microbial inoculation or exogenous protease addition is still warranted. Therefore, experimental objectives were to evaluate the effect on fermentation profile, $\mathrm{N}$ fractions, and ivSD of the following: (1) rehydration and ensiling of dry ground corn; (2) exogenous protease addition to rehydrated un-ensiled and ensiled corn; (3) exogenous protease addition or microbial inoculation in rehydrated ensiled corn; and (4) exogenous protease addition or microbial inoculation in HMC. We hypothesized that rehydration will increase ivSD only when done in conjunction with ensiling; addition of exogenous protease will increase ivSD in rehydrated and HMC; and microbial inoculation will improve fermentation profile and ivSD.

\section{MATERIALS AND METHODS}

\section{Experiments 1, 2, and 3}

Ten kilograms of DGC was obtained from the University of Wisconsin Feed Mill (Arlington, WI) on March 2013 after fine grinding (616 $\mu \mathrm{m}$ of MPS), homogenized, and allocated into 21 samples of approximately $300 \mathrm{~g}$ each using a quartering technique: homogeneous samples were divided into 4 equal subsamples. Two subsamples were saved for later treatment, whereas the 2 other subsamples were rehomogenized and redivided. The process was repeated until 21 subsamples of approximately $300 \mathrm{~g}$ were prepared. The remainder was frozen at $-20^{\circ} \mathrm{C}$ until processed for analysis to characterize the DGC. Samples were randomly assigned to 7 treatments with 3 replications per treatment. The treatments were DGC, DGC rehydrated to a targeted DM content of $70 \%$ (REH), REH treated with exogenous protease (REH+), REH ensiled for $30 \mathrm{~d}$ (ENS), ENS treated with exogenous protease (ENS+), ENS treated with a microbial inoculant (ENSI), and ENS treated with exogenous protease and microbial inoculant (ENSI+). An experimental exogenous bacterial protease produced in Bacillus licheniformis (DSM Nutritional Products, Basel, Switzerland/Novozymes, Bagsvaerd, Denmark) was added at a supplier recommended rate of $1,825 \mathrm{mg}$ of protease per $\mathrm{kg}$ of corn DM to protease treatments, which is equivalent to 136.9 PROT units per $\mathrm{kg}$ of corn DM. One PROT unit is the amount of enzyme that releases $1 \mu \mathrm{mol}$ of $p$-nitroaniline from $1 \mu M$ of substrate (Suc-Ala-Ala-Pro-Phe-pNA) per minute at pH 9.0 and $37^{\circ} \mathrm{C}$. The supplier-recommended application rate $(5 \times$ $10^{4} \mathrm{cfu} / \mathrm{g}$ of rehydrated corn) of a microbial inoculant containing Lactobacillus plantarum, Lactobacillus casei, Enterococcus faecium, and Pediococcus sp. (Silo Charger "D," NU-AG Bosko Inc., Oskaloosa, IA) was applied to the inoculant treatments. Exogenous protease and microbial inoculant were mixed in the same solution before application of ENSI+ treatment.

Samples of DGC, REH, and REH+ were frozen $12 \mathrm{~h}$ after exposure to treatment. Samples of ENS, ENS+, ENSI, and ENSI+ were placed in nylon-polyethylene 
standard barrier vacuum pouches (3.5-mil thickness, $25.4 \times 35.6 \mathrm{~cm}$; Doug Care Equipment Inc., Springville, $\mathrm{CA}$ ) and vacuum heat sealed using an external clamp vacuum machine (Bestvac; distributed by Doug Care Equipment Inc., Springville, CA) immediately after treatment application and stored at room temperature (approximately $20^{\circ} \mathrm{C}$ ) in the dark. After $30 \mathrm{~d}$, samples were immediately frozen at $-20^{\circ} \mathrm{C}$ to stop fermentation and stored until processed for analysis.

Samples were dried at $60^{\circ} \mathrm{C}$ for $48 \mathrm{~h}$ in a forced-air oven to determine DM content, ground to pass either a 1-mm Wiley mill screen (Thomas Scientific, Swedesboro, NJ) before analysis for CP (method 990.03, AOAC International, 2012), borate-phosphate buffer soluble CP (Krishnamoorthy et al., 1982), and starch (Bach Knudsen, 1997, YSI Biochemistry Analyzer, YSI Inc., Yellow Springs, OH) concentrations or a 4-mm Wiley mill screen (Thomas Scientific) before analysis for 7-h ivSD (Richards et al., 1995). Particle size was determined by dry sieving dried, unground samples using a Tyler Ro-Tap Shaker Model RX-29 (Mentor, OH) with sieves of 4,760, 2,380, 1,191, 595, 297, 149, and 63 $\mu \mathrm{m}$ apertures plus the bottom pan; MPS and surface area were calculated using a log normal distribution (Baker and Herrman, 2002). Undried samples were analyzed for $\mathrm{pH}$ and ammonia-N (method 973.49, AOAC International, 2012). Ensiled samples had fermentation profile measured via HPLC as described by Muck and Dickerson (1988). Analysis of DM, CP, soluble CP, ammonia-N, and $\mathrm{pH}$ were performed at the University of Wisconsin-Madison, whereas starch content, ivSD, and fermentation profile analyses were performed at Dairyland Laboratories Inc. (Arcadia, WI). All measurements were performed in duplicate.

Two sub-samples were collected from the remainder of the batch sample using the quartering technique described previously to characterize the DGC (Table 1). Samples were dried at $60^{\circ} \mathrm{C}$ for $48 \mathrm{~h}$ in a forced-air oven to determine DM content, ground to pass a either a 1-mm Wiley mill screen (Thomas Scientific) before sending to Dairyland Laboratories Inc. for analysis for ash (method 942.05, AOAC International, 2012), CP, ether extract (method 920.39, AOAC International, 2012), NDF (method 2002.04, AOAC International, 2012), starch, and zein protein concentration (Nellis et al., 2013). Particle size was determined at the University of Wisconsin-Madison as described previously.

In experiment 1, DGC, REH, and ENS were evaluated in a completely randomized design. Data were analyzed using PROC MIXED of SAS (SAS Institute, 2004 ) with treatment as a fixed effect. Means were determined using the least squares means statement and treatment means were compared using the Bonferroni's $t$-test option after a significant overall treatment $F$ test.
Bonferroni's $t$-test is a sequentially rejective test based on the Holm-Bonferroni method (Holm, 1979). In experiment 2, REH and ENS without or with exogenous protease addition $(\mathrm{REH}+$ and $\mathrm{ENS}+$, respectively) were evaluated in a completely randomized designed in a $2 \times 2$ factorial arrangement of treatments. Data were analyzed using PROC MIXED of SAS (SAS Institute, 2004) with the fixed effects of ensiling, exogenous protease addition and their interaction. In experiment 3 , exogenous protease addition and inoculation in ENS corn (ENS, ENS+, ENSI, and ENSI+) were evaluated in a completely randomized designed in a $2 \times 2$ factorial arrangement of treatments. Data were analyzed using PROC MIXED of SAS (SAS Institute, 2004) with the fixed effects of inoculation, exogenous protease addition, and their interaction. For all 3 experiments, statistical significance and trends were declared at $P \leq$ 0.05 and $P>0.05$ to $P<0.10$, respectively.

\section{Experiment 4}

Ten kilograms of unfermented HMC from the University of Wisconsin-Arlington Agricultural Research Station (Arlington, WI) was obtained in October 2013. The batch sample was obtained after combine harvest and rolling at the silo bagger, homogenized, and divided into 24 subsamples of approximately $300 \mathrm{~g}$ each using the quartering technique described previously. The remainder was frozen at $-20^{\circ} \mathrm{C}$ until processed for analysis to characterize the HMC. Samples were randomly assigned to 8 treatments with 3 replications per treatment. Treatments were a combination of HMC un-inoculated or inoculated with 1 of 3 microbial inoculants and with or without exogenous protease addition.

The same experimental exogenous protease (DSM Nutritional Products/Novozymes) used in experiments 1,2 , and 3 was added at a rate of $1,825 \mathrm{mg}$ of protease per $\mathrm{kg}$ of corn DM to 1 of 4 protease treatments. The inoculant treatments followed the supplier recommended application rate of the respective microbial inoculant as

Table 1. Nutrient composition and particle size of unfermented dry (DGC) and high-moisture (HMC) corn samples

\begin{tabular}{lcc}
\hline Item & $\begin{array}{c}\text { DGC } \\
\text { (experiments 1-3) }\end{array}$ & $\begin{array}{c}\text { HMC } \\
\text { (experiment 4) }\end{array}$ \\
\hline DM (\% as fed) & 87.9 & 72.0 \\
CP (\% of DM) & 8.7 & 8.0 \\
Ether extract (\% of DM) & 3.5 & 3.8 \\
NDF (\% of DM) & 10.6 & 7.9 \\
Starch (\% of DM) & 68.2 & 72.0 \\
Ash (\% of DM) & 1.3 & 1.4 \\
Zein (\% of DM) & 4.7 & 3.6 \\
MPS $^{1}(\mu \mathrm{m})$ & 616 & 1,404 \\
Surface area $\left(\mathrm{cm}^{2} / \mathrm{g}\right)$ & 37 & 31 \\
\hline
\end{tabular}

${ }^{1}$ Mean particle size. 
follows: (1) a control with no added inoculant $(\mathbf{C O N})$; (2) $6.0 \times 10^{5}$ cfu of Lactobacillus buchneri 40788 and 1.5 $\times 10^{5}$ cfu of Pediococcus pentosaceus/g of HMC (LBPP; Biotal Buchneri 500; Lallemand Animal Nutrition, Milwaukee, WI); (3) $6.0 \times 10^{5}$ cfu of L. buchneri $40788 / \mathrm{g}$ of HMC (LB; Biotal Buchneri 40788; Lallemand Animal Nutrition); or (4) $1.2 \times 10^{5}$ cfu of a mixture of P. pentosaceus and Propionibacterium freudenreichii/g of HMC (PP; Biotal Plus II; Lallemand Animal Nutrition). All samples, including the HMC without inoculation or protease addition, received the same amount of double distilled water to ensure protocol similarity among all samples. All samples were vacuum heat sealed in nylon-polyethylene standard barrier vacuum pouches immediately after treatment application as described above. After $30 \mathrm{~d}$, samples were immediately frozen at $-20^{\circ} \mathrm{C}$ to stop fermentation and stored until processed for analysis.

All samples were analyzed in duplicate for DM, $\mathrm{CP}$, borate-phosphate buffer soluble $\mathrm{CP}$, ammonia-N, starch, ivSD, MPS, $\mathrm{pH}$, and fermentation profile as described for experiments 1, 2, and 3. Two subsamples were collected from the batch sample using the quartering technique described previously to characterize the unfermented HMC (Table 1). Samples were analyzed for DM, ash, CP, ether extract, NDF, starch, and zein protein concentrations and MPS as described previously.

In experiment 4, exogenous protease addition and inoculation in HMC were evaluated in a completely randomized designed in a $4 \times 2$ factorial arrangements of treatments. Data were analyzed using PROC MIXED of SAS (SAS Institute, 2004) with the fixed effects of inoculation, exogenous protease addition, and their interaction. Statistical significance and tendencies were declared at $P \leq 0.05$ and $P>0.05$ to $P<0.10$, respectively.

\section{RESULTS AND DISCUSSION}

\section{Experiments 1, 2, and 3}

Effects of rehydration and ensiling on $\mathrm{pH}, \mathrm{N}$ fractions, particle size, and ivSD in dry ground corn are in Table 2 (experiment 1). Targeted DM content was achieved for REH and ENS (69.7\% on average). The $\mathrm{pH}$ was reduced $(P=0.001)$ for ENS compared with DGC and REH due to bacterial fermentation in the mini-silo and suggestive of a good fermentation (Muck, 2010). Concentration of $\mathrm{CP}$ tended $(P=0.10)$ to be greater for ENS than other treatments. Greater CP concentration for fresh than ensiled HMC was previously reported by Kung et al. (2014). Greater ammonia-N and soluble CP concentrations were observed $(P=0.001)$ for ENS compared with DGC and REH. Increases in soluble CP and ammonia- $\mathrm{N}$ with ensiling were previously reported in the literature (Baron et al., 1986; Hoffman et al., 2011; Kung et al., 2014) and coincided with reduced zein protein concentrations (Hoffman et al., 2011; Kung et al., 2014). Furthermore, Kung et al. (2014) discussed that breakdown of albumin, globulin, or glutelin proteins (or a combination of these) may also have occurred. Digestibility of starch is mainly influenced by this hydrophobic starch-protein matrix surrounding starch granules, which impedes microbial attachment and fermentation in the rumen or hydrolytic and enzymatic digestion in the abomasum and small intestine (Giuberti et al., 2014). The reduction in zein protein subunits that cross-link starch granules during the ensiling process (Hoffman et al., 2011) may explain the 13.2 percentage unit increase $(P=0.001)$ in ivSD for ENS compared with DGC and REH. A 6 percentage unit increase in starch ruminal effective disappearance for ensiled compared with unensiled corn was reported by Philippeau and Michalet-Doreau (1998). Benton et al. (2005b) rehydrated and ensiled dry-rolled corn to 28 and $35 \%$ moisture and reported that ruminal in situ DM disappearance increased 17.3 and 39.8 percentage units, respectively, after $28 \mathrm{~d}$ of ensiling. Furthermore, rehydration and ensiling of corn or sorghum increased ADG and feed efficiency in beef steers (Stock et al., 1987; Benton et al., 2005a). Surface area was greater $\left(P=0.03 ; 41.7\right.$ vs. $37.7 \mathrm{~cm}^{2} / \mathrm{g}$, respectively) and MPS tended to be reduced ( $P=0.07 ; 530$ vs. $613 \mu \mathrm{m}$, respectively) for REH compared with DGC. This may be related to disassociation of particles due to rehydration, but the magnitude of change was not sufficient to explain the increased REH ivSD.

Effects of ensiling and exogenous protease addition on $\mathrm{pH}, \mathrm{N}$ fractions, particle size, and ivSD in rehydrated corn are in Table 3 (experiment 2). Content of DM tended $(P=0.10)$ to be 2.3 percentage units lower and $\mathrm{CP}$ content was $(P=0.01) 0.6$ percentage units greater for ENS than REH. The difference in DM content is likely related to DM loss during aerobic respiration or the fermentation phase in ENS (McDonald et al., 1991). In addition, DM and CP concentrations were unaffected $(P>0.10)$ by exogenous protease addition in agreement with Kung et al. (2014). Similar to experiment 1 , a decrease in $\mathrm{pH}$ and an increase in ammonia- $\mathrm{N}$ concentrations were observed $(P=0.001)$ with ensiling, but these parameters were unaffected $(P$ $>0.10)$ by addition of exogenous protease. Kung et al. (2014) reported that exogenous protease addition increased $\mathrm{pH}$ and ammonia-N in HMC ensiled for 70 and $140 \mathrm{~d}$, but not in fresh samples. These findings suggest that exogenous protease may take longer than 30 $\mathrm{d}$ to affect ammonia- $\mathrm{N}$ concentrations in ensiled corn. 
Table 2. Effect of rehydration and ensiling on $\mathrm{pH}, \mathrm{N}$ fractions, particle size, and ruminal in vitro starch digestibility in dry ground corn (experiment 1$)^{1}$

\begin{tabular}{|c|c|c|c|c|c|}
\hline Intake & DGC & $\mathrm{REH}$ & ENS & $\mathrm{SE}$ & $P$-value \\
\hline \multicolumn{6}{|l|}{ Fermentation profile } \\
\hline \multicolumn{6}{|l|}{ Nutrient } \\
\hline DM (\% of as fed) & $88.0^{\mathrm{a}}$ & $70.9^{\mathrm{b}}$ & $68.4^{\mathrm{b}}$ & 1.3 & 0.001 \\
\hline $\mathrm{CP}(\%$ of $\mathrm{DM})$ & 8.5 & 8.3 & 8.9 & 0.1 & 0.10 \\
\hline Soluble CP (\% of $\mathrm{CP})$ & $18.0^{\mathrm{b}}$ & $13.1^{\mathrm{c}}$ & $22.5^{\mathrm{a}}$ & 1.2 & 0.01 \\
\hline Ammonia- $\mathrm{N}$ ( $\%$ of $\mathrm{CP})$ & $0.04^{\mathrm{b}}$ & $0.08^{\mathrm{b}}$ & $1.98^{\mathrm{a}}$ & 0.07 & 0.001 \\
\hline $\operatorname{ivSD}^{2}(\%$ of starch $)$ & $52.6^{\mathrm{b}}$ & $50.8^{\mathrm{b}}$ & $64.9^{\mathrm{a}}$ & 1.9 & 0.001 \\
\hline \multicolumn{6}{|l|}{ Particle size } \\
\hline $\operatorname{MPS}^{3}(\mu \mathrm{m})$ & 613 & 530 & 591 & 20 & 0.07 \\
\hline Surface area $\left(\mathrm{cm}^{2} / \mathrm{g}\right)$ & $37.7^{\mathrm{a}}$ & $41.7^{\mathrm{b}}$ & $40.3^{\mathrm{ab}}$ & 0.7 & 0.03 \\
\hline
\end{tabular}

However, results from experiment 4 do not support this premise (refer to Table 5), and further research is warranted. An ensiling $\times$ exogenous protease addition interaction was observed $(P=0.001)$ for soluble $\mathrm{CP}$ due to similar soluble $\mathrm{CP}$ concentrations for $\mathrm{REH}+$ and ENS. In addition, although exogenous protease addition increased soluble $\mathrm{CP}$ concentrations in both REH and ENS, the magnitude of the increase was greater for ENS (32.3 vs. 5.7 units). Exogenous protease addition was reported to increase soluble $\mathrm{CP}$ in HMC ensiled for 70 and $140 \mathrm{~d}$, but not fresh samples (Kung et al., 2014). In the current experiment, ensiling and exogenous protease addition increased $(P<0.05)$ ivSD. As previously discussed, greater ivSD for ENS compared with $\mathrm{REH}$ is likely related to disruption during the ensiling process of the protein-matrix cross-linked to starch granules (Hoffman et al., 2011). Likewise, exogenous protease addition at ensiling was previously reported to reduce zein protein concentrations and increase ivSD in HMC (Kung et al., 2014). Although no interaction was observed $(P=0.26)$ for ivSD, exogenous protease addition was more effective in ENS than REH (6.4 vs. 2.6 percentage units increase). This observation is in agreement with the soluble CP measurements, which increased with exogenous protease addition to a greater extent when samples were ensiled. Similar results were reported by Kung et al. (2014). These results suggest that addition of exogenous protease at ensiling is more effective than treating REH for short periods. Similar to experiment 1, greater surface area and reduced MPS were observed $(P=0.01)$ for REH compared with ENS. Exogenous protease addition did not affect particle size measurements.

Effects of microbial inoculation and exogenous protease addition on fermentation profile, particle size, and
ivSD in rehydrated corn ensiled for $30 \mathrm{~d}$ are in Table 4 (experiment 3). Microbial inoculation reduced $\mathrm{pH}$ ( $P=0.001 ; 3.99$ vs. 4.40 on average) compared with ENS due to greater lactic acid concentrations $(P=$ $0.001 ; 1.69$ vs. $0.95 \%$ of DM on average). Total acid concentrations tended $(P=0.09)$ to be greater with microbial inoculation despite lower acetic $(P=0.02)$ and propionic $(P=0.001)$ acid concentrations. Furthermore, concentrations of ethanol were reduced $(P=$ 0.001 ) with microbial inoculantion. Overall, inoculation with lactate-producing bacteria reduces $\mathrm{pH}$ and shifts fermentation toward lactic rather than acetic and propionic acids in varied ensiled feeds, but responses may be variable (Muck, 2010). Inoculating HMC with $2 \times$ $10^{6} \mathrm{cfu} / \mathrm{g}$ of a mixture containing L. plantarum, Streptococcus faecium, and Pediococcus acidilactici reduced $\mathrm{pH}$ in 1 of 2 experiments, whereas organic acid and ethanol concentrations were minimally affected in both trials (Wardynski et al., 1993). In contrast, lower pH, 2-fold greater lactate, and lower ethanol concentrations were observed when HMC was inoculated with a rate of 2.6 $\times 10^{7} \mathrm{cfu} / \mathrm{kg}$ of HMC of a mixture containing L. plantarum, Lactobacillus brevis, and P. acidilactici (Faber et al., 1989). Although not measured in the present study, lower ethanol concentration may be an indication of reduced yeast counts (Pahlow et al., 2003). Combined, these results emphasize the benefits of microbial inoculation on fermentation profile in rehydrated corn. Except for the reduced $(P=0.02)$ ethanol concentrations, exogenous protease addition did not affect $(P>$ $0.10)$ fermentation profile. Exogenous protease addition was previously reported to increase $\mathrm{pH}$ and lactate and ethanol concentrations (Kung et al., 2014).

A tendency $(P=0.10)$ for greater DM content was observed with microbial inoculation, but not $(P=0.85)$ 
Table 3. Effect of ensiling and protease addition on $\mathrm{pH}, \mathrm{N}$ fractions, particle size, and ruminal in vitro starch digestibility in rehydrated corn (experiment 2$)^{1}$

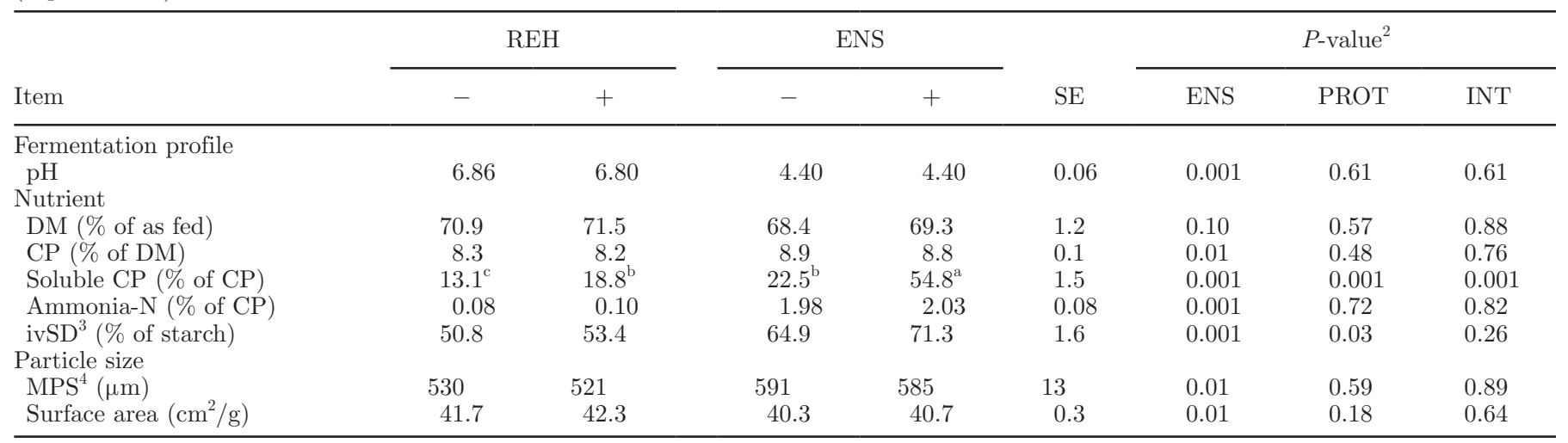

${ }^{\mathrm{a}-\mathrm{c}}$ Means in the same row with different superscripts differ $(P \leq 0.05)$.

${ }^{1}$ Treatments were un-ensiled rehydrated dry corn (REH) or ensiled for $30 \mathrm{~d}(\mathrm{ENS})$ and without $(-)$ or with exogenous protease addition $(+)$.

${ }^{2}$ Effects of ensiling (ENS), exogenous protease addition (PROT), and their interaction (INT).

${ }^{3}$ Ruminal in vitro starch digestibility at $7 \mathrm{~h}$.

${ }^{4}$ Mean particle size.

protease addition. Concentration of $\mathrm{CP}$ was similar $(P$ $>0.10)$ among treatments. An inoculation $\times$ exogenous protease addition interaction was observed $(P=0.03)$ for soluble CP. Although exogenous protease addition increased soluble $\mathrm{CP}$ in both un-inoculated and inoculated samples, concentrations were greater for ENS+ than ENSI+. Although no other interactions were observed $(P>0.10)$, ENSI+ had numerically lower $\mathrm{pH}$ and acetate, propionate, ethanol, and ammonia-
$\mathrm{N}$ concentrations and greater lactate concentrations. Addition of exogenous protease increased proteolysis and may have increased the availability of peptides and free AA for lactate-producing bacteria growth, thereby limiting yeast growth, and as a consequence, ethanol production (Pahlow et al., 2003; Hoffman et al., 2011). Lactic acid concentrations were greatest in HMC when lactate-producing microbial inoculants were combined with the addition of exogenous protease in experiment

Table 4. Effects of microbial inoculation and protease addition on $\mathrm{pH}, \mathrm{N}$ fractions, particle size, and ruminal in vitro starch digestibility in rehydrated corn ensiled for $30 \mathrm{~d}$ (experiment 3 )

\begin{tabular}{|c|c|c|c|c|c|c|c|c|}
\hline \multirow[b]{2}{*}{ Item } & \multicolumn{2}{|c|}{ ENS } & \multicolumn{2}{|c|}{ ENSI } & \multirow[b]{2}{*}{$\mathrm{SE}$} & \multicolumn{3}{|c|}{$P$-value ${ }^{2}$} \\
\hline & - & + & - & + & & INOC & PROT & INT \\
\hline \multicolumn{9}{|l|}{ Fermentation profile } \\
\hline $\mathrm{pH}$ & 4.40 & 4.40 & 4.07 & 3.92 & 0.06 & 0.001 & 0.22 & 0.22 \\
\hline Lactic acid (\% of DM) & 0.95 & 0.95 & 1.52 & 1.85 & 0.11 & 0.001 & 0.18 & 0.18 \\
\hline Acetic acid (\% of DM) & 0.53 & 0.51 & 0.32 & 0.19 & 0.08 & 0.02 & 0.36 & 0.53 \\
\hline Propionic acid (\% of DM) & 0.15 & 0.14 & 0.04 & 0.01 & 0.02 & 0.001 & 0.42 & 0.67 \\
\hline \multicolumn{9}{|l|}{ Nutrient } \\
\hline DM ( $\%$ of as fed) & 68.4 & 69.2 & 71.6 & 71.3 & 1.4 & 0.10 & 0.85 & 0.66 \\
\hline $\mathrm{CP}(\%$ of $\mathrm{DM})$ & 8.9 & 8.8 & 9.1 & 9.2 & 0.1 & 0.14 & 0.91 & 0.61 \\
\hline Soluble CP (\% of CP) & $22.5^{\mathrm{c}}$ & $54.8^{\mathrm{a}}$ & $26.2^{\mathrm{c}}$ & $47.3^{\mathrm{b}}$ & 2.0 & 0.37 & 0.001 & 0.03 \\
\hline Ammonia-N (\% of CP) & 1.98 & 2.03 & 1.62 & 1.52 & 0.10 & 0.01 & 0.84 & 0.48 \\
\hline ivSD $^{3}$ (\% of starch) & 64.9 & 71.3 & 67.9 & 71.4 & 1.6 & 0.38 & 0.02 & 0.39 \\
\hline \multicolumn{9}{|l|}{ Particle size } \\
\hline
\end{tabular}

${ }^{\mathrm{a}-c}$ Means in the same row with different superscripts differ $(P \leq 0.05)$.

${ }^{1}$ Treatments were rehydrated dry corn ensiled for $30 \mathrm{~d}$ treated without (ENS) or with microbial inoculant (ENSI) and without (-) or with exogenous protease addition $(+)$.

${ }^{2}$ Effects of microbial inoculation (INOC), exogenous protease addition (PROT), and their interaction (INT).

${ }^{3}$ Ruminal in vitro starch digestibility at $7 \mathrm{~h}$.

${ }^{4}$ Mean particle size. 
4 (Figure 1A) supporting our premise. However, because neither bacterial nor yeast counts were measured in the present study, further investigation is warranted. Ammonia- $\mathrm{N}$ concentrations decreased $(P=0.01)$ with microbial inoculation, which may be another indication of increased uptake of peptides and free AA for bacterial growth in the present study. Alternatively, lower ammonia-N concentration may be related to greater fermentation efficiency due to microbial inoculation, which in turn inhibited undesired microorganisms (Pahlow et al., 2003). Microbial inoculation did not reduce ammonia- $\mathrm{N}$ concentration in trials of Faber et al. (1989) or Wardynski et al. (1993). Exogenous protease addition did not affect ammonia- $\mathrm{N}$ concentrations. These data are in contrast to Kung et al. (2014), where ammonia- $\mathrm{N}$ and soluble $\mathrm{CP}$ concentrations were increased in HMC treated with exogenous protease at ensiling. The addition of exogenous protease, but not bacterial inoculation, increased ivSD (5 percentage units; $P=0.02$ ). These results support that proteolysis may be the primary mechanism for the breakdown of zein proteins during the ensiling process rather than protein solubilization caused by greater acid concentrations (Hoffman et al., 2011). Greater surface area and lower MPS were observed $(P=0.01)$ with inoculation. Similar to experiment 2 , protease addition did not affect MPS.

\section{Experiment 4}

Effects of microbial inoculation and exogenous protease addition on fermentation profile, particle size, and ivSD in HMC ensiled for $30 \mathrm{~d}$ are in Tables 5 and 6 , respectively. Measurements of $\mathrm{pH}$ were $(P=0.001)$ lowest for PP and LBPP, followed by LB, and highest for CON in relationship to greater lactic acid concentrations $(P=0.001)$ for LBPP and PP compared with LB and CON. Inoculation with lactate-producing bacteria generally increases lactic acid concentrations and decreases pH (Muck, 2010). In addition, the dissociation constant of lactate is lower than acetate (Muck, 2010), which explains the lower $\mathrm{pH}$ for PP and LBPP than LB. A microbial inoculation $\times$ exogenous protease addition interaction was observed $(P=0.001$; Figure 1A) for lactic acid. Exogenous protease addition increased $(P<0.05)$ or tended $(P<0.10)$ to increase lactic acid concentrations in LBPP and PP, respectively, but not $\mathrm{LB}$ and CON. Proteolysis due to exogenous protease addition and corresponding greater availability of peptides and free AA may create an opportunity for greater lactate-producing bacteria growth and lactic acid production (Pahlow et al., 2003; Hoffman et al., 2011) in LBPP and PP. Acetic acid concentrations were $(P=$ 0.001) greatest for LB, followed by LBPP and CON,

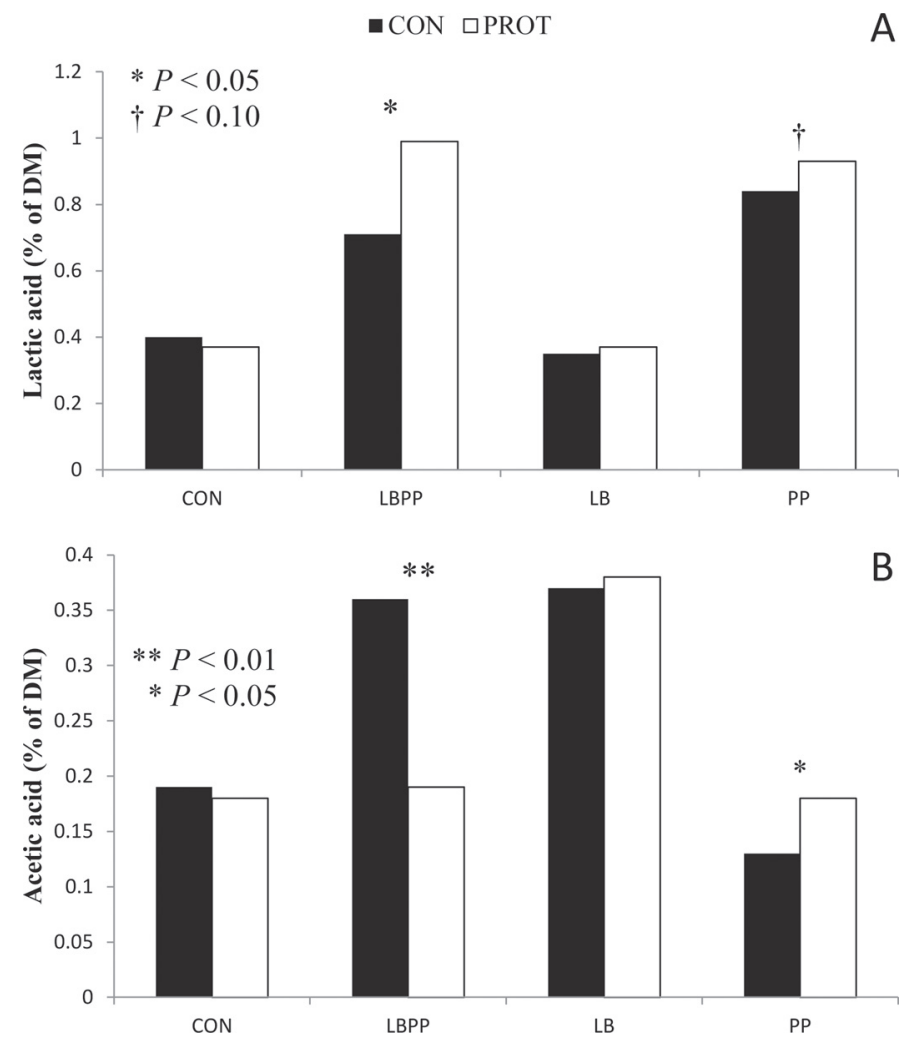

Figure 1. Interaction between microbial inoculation and exogenous protease addition on lactic (panel A; $P=0.001$; SEM $=0.01$ ) and acetic (panel $\mathrm{B} ; P=0.001 ; \mathrm{SEM}=0.03$ ) acid concentrations in high-moisture corn ensiled for $30 \mathrm{~d}$. Treatments were high-moisture corn with (PROT) or without (control; CON) an exogenous protease and with or without microbial inoculation as follows: $6.0 \times 10^{5}$ cfu of Lactobacillus buchneri 40788 and $1.5 \times 10^{5}$ cfu of Pediococcus pentosaceus/g of HMC (LBPP); $6.0 \times 10^{5} \mathrm{cfu}$ of L. buchneri 40788/g of HMC (LB); and $1.2 \times 10^{5}$ cfu of a mixture of $P$. pentosaceus and Propionibacterium freudenreichii/g of HMC (PP).

and lowest for PP. Greater acetic acid concentrations for $\mathrm{LB}$ may explain the lower $\mathrm{pH}$ values relative to $\mathrm{CON}$. Hoffman et al. (2011) observed lower $\mathrm{pH}$ and greater acetic acid concentrations when HMC was inoculated with $6 \times 10^{4}$ cfu of L. buchneri $40788 / \mathrm{g}$ of HMC. In contrast, Kung et al. (2007) reported greater $\mathrm{pH}$ values despite greater acetic acid concentrations when HMC was inoculated with 4,6 , or $8 \times 10^{5}$ cfu of $L$. buchneri $40788 / g$. Typically, inoculation with LB has a slower fermentation than homolactic acid bacteria (Muck, 2010). Although LB growth occurs after only 2 d of ensiling, LB greatly shifts fermentation by converting lactic acid to acetic acid and 1,2-propanediol after 45 to 60 d of ensiling (Schmidt et al., 2009). Fermentation lasted only $30 \mathrm{~d}$ in the present study, which may explain the similar lactate concentration and lower $\mathrm{pH}$ than CON. A microbial inoculation $\times$ exogenous protease addition interaction was observed $(P=0.001$; Figure 1A) for acetic acid. Exogenous protease addition increased $(P$ 
Table 5. Effects of microbial inoculation on $\mathrm{pH}, \mathrm{N}$ fractions, particle size, and ruminal in vitro starch digestibility in high-moisture corn ensiled for $30 \mathrm{~d}$ (experiment 4)

\begin{tabular}{|c|c|c|c|c|c|c|}
\hline \multirow[b]{2}{*}{ Item } & \multicolumn{4}{|c|}{ Inoculant $^{1}$} & \multirow[b]{2}{*}{ SEM } & \multirow[b]{2}{*}{$P<$} \\
\hline & $\mathrm{CON}$ & LBPP & LB & $\mathrm{PP}$ & & \\
\hline Lactic acid (\% of DM) & $0.39^{\mathrm{b}}$ & $0.85^{\mathrm{a}}$ & $0.36^{\mathrm{b}}$ & $0.89^{\mathrm{a}}$ & 0.02 & 0.001 \\
\hline Acetic acid ( $\%$ of DM) & $0.19^{\mathrm{c}}$ & $0.27^{\mathrm{b}}$ & $0.38^{\mathrm{a}}$ & $0.15^{\mathrm{d}}$ & 0.01 & 0.001 \\
\hline Ethanol (\% of DM) & $0.32^{\mathrm{a}}$ & $0.20^{\mathrm{b}}$ & $0.34^{\mathrm{a}}$ & $0.21^{\mathrm{b}}$ & 0.01 & 0.001 \\
\hline $\mathrm{DM}(\%$ of as fed) & 72.2 & 72.0 & 72.7 & 73.9 & 0.5 & 0.06 \\
\hline $\mathrm{CP}(\%$ of $\mathrm{DM})$ & 8.2 & 8.2 & 8.3 & 8.2 & 0.1 & 0.37 \\
\hline Soluble CP (\% of CP) & $31.8^{\mathrm{b}}$ & $35.7^{\mathrm{a}}$ & $34.7^{\mathrm{a}}$ & $36.6^{\mathrm{a}}$ & 0.8 & 0.01 \\
\hline Ammonia-N ( $\%$ of $\mathrm{CP})$ & $1.29^{\mathrm{b}}$ & $1.83^{\mathrm{a}}$ & $1.81^{\mathrm{a}}$ & $1.75^{\mathrm{a}}$ & 0.07 & 0.001 \\
\hline $\operatorname{ivSD}^{2}(\%$ of starch $)$ & 47.0 & 49.0 & 47.1 & 49.5 & 1.7 & 0.64 \\
\hline \multicolumn{7}{|l|}{ Particle size } \\
\hline $\mathrm{MPS}^{3}(\mu \mathrm{m})$ & 1,453 & 1,720 & 1,606 & 1,609 & 69 & 0.10 \\
\hline
\end{tabular}

${ }^{\mathrm{a}-\mathrm{d}}$ Means in the same row with different superscripts differ $(P \leq 0.05)$.

${ }^{1} \mathrm{CON}=$ control; LBPP $=6.0 \times 10^{5} \mathrm{cfu}$ of Lactobacillus buchneri 40788 and $1.5 \times 10^{5} \mathrm{cfu}$ of Pediococcus pentosaceus $/ \mathrm{g}$ of HMC; LB $=6.0 \times$ $10^{5}$ cfu of L. buchneri 40788/g of HMC; PP $=1.2 \times 10^{5} \mathrm{cfu}$ of a mixture of P. pentosaceus and Propionibacterium freudenreichii/g of HMC.

${ }^{2}$ Ruminal in vitro starch digestibility at $7 \mathrm{~h}$.

${ }^{3}$ Mean particle size.

$<0.05)$ acetic acid concentrations when HMC was inoculated with PP, but decreased $(P<0.05)$ acetic acid concentrations when HMC was inoculated with LBPP. Strains of lactate-producing bacteria are selected by companies to be dominant and ferment faster than epiphytic bacteria, whereas LB has slower fermentation rates but greater tolerance to low $\mathrm{pH}$ and lack of substrates (Schmidt et al., 2009; Muck, 2010). Greater lactate-producing bacterial growth for LBPP may have limited the initial growth of $L$. buchneri when exogenous protease was added in conjunction with LBPP. However, similar initial growth of L. buchneri was observed by Schmidt et al. (2009) when alfalfa silage was inoculated with $4 \times 10^{5}$ cfu of L. buchneri $40788 / \mathrm{g}$ or $4.5 \times 10^{5} \mathrm{cfu}$ of $L$. buchneri 40788 and $1 \times 10^{5}$ cfu of P. pentosaceus/g of fresh forage. Measurements of bacterial growth were not performed in the present study, and further research is warranted to elucidate the mechanism that affects fermentation end products of varied bacteria with exogenous protease addition. Ethanol concentration was decreased $(P=0.001)$ for LBPP and PP compared with LB and CON. Lower ethanol concentrations were reported when HMC was inoculated with a mixture of lactate-producing bacteria and thought to be related to reduced substrate availability for ethanol production by yeasts, coliform bacteria, and plant enzymes (Faber et al., 1989). Lack of difference in ethanol concentrations between LB and CON was previously reported by Kung et al. (2007). Exogenous protease addition did not affect $\mathrm{pH}$ (4.27 on average) or ethanol concentrations ( $0.27 \%$ on average).
Exogenous protease addition was previously reported to increase $\mathrm{pH}$ and lactate and ethanol concentrations (Kung et al., 2014). In contrast, lower ethanol concentration was observed in experiment 3 . Possible reasons for the variation on ethanol concentration response to exogenous protease addition are unclear, and further research is warranted.

Concentrations of DM and $\mathrm{CP}$ were unaffected $(P>$ $0.10)$ by protease addition and averaged 72.7 and $8.2 \%$, respectively. Content of DM tended $(P=0.06)$ to be 1.6-\% units higher for PP than other treatments, but $\mathrm{CP}$ concentration did not differ $(P=0.37)$. Greater ammonia-N and soluble $\mathrm{CP}$ concentrations were observed $(P=0.001)$ with exogenous protease addition at ensiling. Hoffman et al. (2011) reported that lower concentrations of zein proteins, a well-known inhibitor of rumen microbial fermentation and enzymatic digestion of starch (Giuberti et al., 2014), were associated with greater ammonia- $\mathrm{N}$ and soluble $\mathrm{CP}$ concentrations after $240 \mathrm{~d}$ of ensiling. Although zein proteins were not measured in the present study, greater ammonia-N and soluble CP concentrations were observed by Kung et al. (2014) and explained by reduced concentrations of zein proteins. In support of this premise and similar to experiments 2 and 3 , we observed a 7.5 percentage unit increase in ivSD with the addition of protease $(P$ $=0.001 ; 44.4$ vs. $51.9 \%)$. Although both ammonia- $\mathrm{N}$ and soluble $\mathrm{CP}$ were increased $(P=0.001)$ by all $3 \mathrm{mi}-$ crobial inoculants, ivSD was unaffected by inoculation (48.2\% on average). Inoculation with lactate-producing bacteria did not increase ammonia- $\mathrm{N}$ concentrations 
Table 6. Effects of exogenous protease addition on $\mathrm{pH}, \mathrm{N}$ fractions, particle size, and ruminal in vitro starch digestibility in high-moisture corn ensiled for $30 \mathrm{~d}$ (experiment 4)

\begin{tabular}{|c|c|c|c|c|}
\hline \multirow[b]{2}{*}{ Item } & \multicolumn{2}{|c|}{ Protease } & \multirow[b]{2}{*}{ SEM } & \multirow[b]{2}{*}{$P<$} \\
\hline & - & + & & \\
\hline \multicolumn{5}{|l|}{ Fermentation profile } \\
\hline $\mathrm{pH}$ & 4.29 & 4.25 & 0.02 & 0.12 \\
\hline Lactic acid (\% of DM) & 0.58 & 0.67 & 0.02 & 0.001 \\
\hline Acetic acid (\% of DM) & 0.26 & 0.23 & 0.01 & 0.01 \\
\hline Ethanol $(\%$ of DM) & 0.28 & 0.26 & 0.01 & 0.29 \\
\hline Total acids (\% of DM) & 0.84 & 0.90 & 0.02 & 0.04 \\
\hline \multicolumn{5}{|l|}{ Nutrient } \\
\hline DM (\% of as fed) & 72.3 & 73.1 & 0.4 & 0.14 \\
\hline $\mathrm{CP}(\%$ of $\mathrm{DM})$ & 8.2 & 8.2 & 0.1 & 0.91 \\
\hline Soluble CP (\% of CP) & 32.7 & 36.7 & 0.5 & 0.001 \\
\hline Ammonia-N (\% of CP) & 1.48 & 1.85 & 0.05 & 0.001 \\
\hline $\operatorname{ivSD}^{1}(\%$ of starch) & 44.4 & 51.9 & 1.2 & 0.001 \\
\hline \multicolumn{5}{|l|}{ Particle size } \\
\hline $\operatorname{MPS}^{2}(\mu \mathrm{m})$ & 1,658 & 1,537 & 49 & 0.10 \\
\hline Surface area $\left(\mathrm{cm}^{2} / \mathrm{g}\right)$ & 29.0 & 30.5 & 2.2 & 0.29 \\
\hline
\end{tabular}

${ }^{1}$ Ruminal in vitro starch digestibility at $7 \mathrm{~h}$.

${ }^{2}$ Mean particle size.

in trials of Faber et al. (1989) and Wardyinski et al. (1993). In contrast, increases in ammonia-N but not soluble CP concentrations were reported when HMC was inoculated with $6 \times 10^{4} \mathrm{cfu}$ of $\mathrm{L}$. buchneri/g of HMC (Hoffman et al., 2011). In addition, these authors reported that zein protein concentrations were unaffected by microbial inoculation. Based on the inverse relationship between $\mathrm{pH}$ and ivSD reported by Ferraretto et al. (2014), it was hypothesized that perhaps microbial inoculation would increase lactic and acetic acid concentrations and correspondingly lower $\mathrm{pH}$, which in turn would enhance the solubilization of zein proteins and increase ivSD. Although effects of microbial inoculation on zein protein concentrations have been reported previously (Hoffman et al., 2011), to our knowledge this is the first study evaluating effects of microbial inoculation on ivSD. Even though effects on zein protein concentration were not measured in the present study, because microbial inoculation did not increase ivSD, either acid concentration was not increased enough to solubilize zein proteins due to the shorter duration of fermentation or solubilization is not a primary mechanism of zein protein degradation during ensiling.

\section{CONCLUSIONS}

Rehydration increased ivSD of ground dry shelled corn only when ensiled. These results suggest that ensiling rehydrated corn is a viable alternative for dairy producers in areas where weather conditions challenge optimal harvest and storage of HMC. Under the conditions of these experiments, exogenous protease addition increased ivSD in un-ensiled and ensiled rehydrated corn, but benefits were greater when rehydrated corn was allowed to ferment. Addition of exogenous protease to HMC also increased ivSD. Microbial inoculation decreased $\mathrm{pH}$ and increased organic acid concentrations in rehydrated corn and HMC. However, microbial inoculation had no effect on ivSD, suggesting that proteolysis is the main mechanism responsible for breakdown of zein proteins during ensiling. The results highlight the importance of microbial inoculants for improving fermentation profile in HMC.

\section{ACKNOWLEDGMENTS}

Appreciation is extended to the staff at the University of Wisconsin-Madison Agricultural Research Station for HMC harvest; Patrick Hoffman (Vita Plus Corporation, Madison, WI) for advice on methodologies; DSM Nutritional Products/Novozymes for providing the exogenous protease; and Ross Dale (NU-AG Bosko Inc.) for providing the microbial inoculant used in experiment 3; and Renato Schmidt (Lallemand Animal Nutrition) for providing the microbial inoculants used in experiment 4 and for early review of the manuscript.

\section{REFERENCES}

AOAC International. 2012. Official Methods of Analysis. 19th ed. AOAC Int., Arlington, VA.

Bach Knudsen, K. E. 1997. Carbohydrate and lignin contents of plant materials used in animal feeding. Anim. Feed Sci. Technol. 67:319338.

Baker, S., and T. Herrman. 2002. Evaluating particle size. MF-2051. Kansas State Univ. Coop Ext. Serv., Manhattan, KS. 
Baron, V. S., K. R. Stevenson, and J. G. Buchanan-Smith. 1986. Proteolysis and fermentation of corn-grain ensiled at several moisture levels and under several simulated storage methods. Can. J. Anim. Sci. 66:451-461.

Benton, J. R., G. E. Erickson, T. J. Klopfenstein, C. N. Macken, and K. J. Vander Pol. 2005a. Effects of corn moisture and degradable intake protein concentration on finishing cattle performance. Nebraska Beef Cattle Reports, pp. 28-30.

Benton, J. R., T. Klopfenstein, and G. E. Erickson. 2005b. Effects of corn moisture and length of ensiling on dry matter digestibility and rumen degradable protein. Nebraska Beef Cattle Reports, pp. $31-33$.

Bitencourt, L. L. 2012. Substituição de milho moido por milho reidratado e ensilado ou melaço de soja em vacas leiteiras. MS Thesis, Universidade Federal de Lavras, MG, Brazil.

Faber, D. A., J. G. Linn, and D. E. Otterby. 1989. Effect of a bacterial inoculant on the fermentation of high moisture shelled and ear corn. J. Dairy Sci. 72:1234-1242.

Ferraretto, L. F., P. M. Crump, and R. D. Shaver. 2013. Effect of cereal grain type and corn grain harvesting and processing methods on intake, digestion and milk production by dairy cows through a meta-analysis. J. Dairy Sci. 96:533-550.

Ferraretto, L. F., K. Taysom, D. Taysom, R. D. Shaver, and P. C. Hoffman. 2014. Relationships between dry matter content, ensiling, ammonia-nitrogen, and ruminal in vitro starch digestibility in high-moisture corn samples. J. Dairy Sci. 97:3221-3227.

Firkins, J. L., M. L. Eastridge, N. R. St-Pierre, and S. M. Noftsger. 2001. Effects of grain variability and processing on starch utilization by lactating dairy cattle. J. Anim. Sci. 79 (E. Suppl.): E218E238.

Giuberti, G., A. Gallo, F. Masoero, L. F. Ferraretto, P. C. Hoffman, and R. D. Shaver. 2014. Factors affecting starch utilization in large animal food production system: A review. Starke 66:72-90.

Goodrich, R. D., F. M. Byers, and J. C. Meiske. 1975. Influence of moisture content, processing and reconstitution on the fermentation of corn grain. J. Anim. Sci. 41:876-881.

Hoffman, P. C., N. M. Esser, R. D. Shaver, W. K. Coblentz, M. P. Scott, A. L. Bodnar, R. J. Schmidt, and R. C. Charley. 2011. Influence of ensiling time and inoculation on alteration of the starchprotein matrix in high-moisture corn. J. Dairy Sci. 94:2465-2474.

Holm, S. 1979. A simple sequentially rejective multiple test procedure. Scand. J. Stat. 6:65-70.

Krishnamoorthy, U., T. V. Muscato, C. J. Sniffen, and P. J. Van Soest. 1982. Borate phosphate procedure as detailed in nitrogen fractions in selected feedstuffs. J. Dairy Sci. 65:217-225.

Kung, L., R. J. Schmidt, T. E. Ebling, and W. Hu. 2007. The effect of Lactobacillus buchneri 40788 on the fermentation and aerobic stability of ground and whole high-moisture corn. J. Dairy Sci. 90:2309-2314.

Kung, L. Jr., M. C. Windle, and N. Walker. 2014. The effect of an exogenous protease on the fermentation and nutritive value of highmoisture corn. J. Dairy Sci. 97:1707-1712.

McDonald, P., A. R. Henderson, and S. J. E. Heron. 1991. The Biochemistry of Silage. 2nd ed. Chalcombe Publications, Marlow, Bucks, UK.

Muck, R. E. 2010. Silage microbiology and its control through additives. Rev. Bras. Zootec. 39:183-191. (Supl. Especial).

Muck, R. E., and J. T. Dickerson. 1988. Storage temperature effects on proteolysis in alfalfa silage. Trans. ASABE 31:1005-1009.

Nellis, S. E., P. C. Hoffman, and R. D. Shaver. 2013. Technical note: A modified method to quantify prolamin proteins in dry and highmoisture corn. J. Dairy Sci. 96:4647-4652.

NRC. 2001. Nutrient Requirements of Dairy Cattle. 7th rev. ed. Natl. Acad. Sci., Washington, DC.

Pahlow, G., R. E. Muck, F. Driehuis, S. J. W. H. Oude Elferink, and S. F. Spoelstra. 2003. Microbiology of ensiling. Pages 31-93 in Silage Science and Technology. D. R. Buxton, R. E. Muck, and J. H Harrison, ed. American Society of Agronomy, Madison, WI.

Philippeau, C., and B. Michalet-Doreau. 1998. Influence of genotype and ensiling of corn grain on in situ degradation of starch in the rumen. J. Dairy Sci. 81:2178-2184.

Richards, C. J., J. F. Peterson, R. A. Britton, R. A. Stock, and C. R. Krehbiel. 1995. In vitro starch disappearance procedure modifications. Anim. Feed Sci. Technol. 55:35-45.

SAS Institute. 2004. SAS/STAT 9.1 User's Guide. Version 9.1 ed. SAS Institute Inc., Cary, NC.

Schmidt, R. J., W. Hu, J. A. Mills, and L. Kung Jr.. 2009. The development of lactic acid bacteria and Lactobacillus buchneri and their effects on the fermentation of alfalfa silage. J. Dairy Sci. 92:5005-5010.

Stock, R. A., D. R. Brink, K. K. Kreikemeier, and K. K. Smith. 1987. Evaluation of early-harvested and reconstituted sorghum in finishing steers. J. Anim. Sci. 65:548-556.

USDA-ERS. 2015. Feed grains database: Yearbook tables. United States Department of Agriculture. Accessed Apr. 2, 2015. http:/ www.ers.usda.gov/data-products/feed-grains-database/feedgrains-yearbook-tables.aspx\#26766.

Wardynski, F. A., S. R. Rust, and M. T. Yokoyama. 1993. Effect of microbial inoculation of high-moisture corn on fermentation characteristics, aerobic instability, and cattle performance. J. Anim. Sci. 71:2246-2252. 